\title{
Depositional redox conditions of the Grybów Succession (Oligocene, Polish Carpathians) in the light of petrological and geochemical indices
}

\author{
Patrycja WÓJCIK-TABOL ${ }^{1, *}$
}

1 Jagiellonian University, Institute of Geological Sciences, Oleandry 2a, 30-063, Kraków, Poland

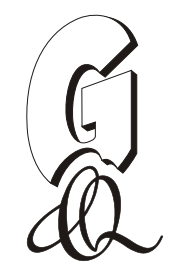

Wójcik-Tabol, P., 2015. Depositional redox conditions of the Grybów Succession (Oligocene, Polish Carpathians) in the light of petrological and geochemical indices. Geological Quarterly, 59 (4): 603-614, doi: 10.7306/gq.1240

\begin{abstract}
This study details the petrology and chemistry of the Oligocene succession of the Grybów Nappe in its stratotype-locality in the Grybów tectonic window (Polish Carpathians). The section studied is composed of the Sub-Grybów Beds, the Grybów Marl Formation (GMF), and the Cergowa Beds, representing the middle to upper part of the Oligocene succession. The rocks studied consist of quartz, calcite, Na-plagioclase, muscovite and clay minerals (illite-smectite with $25-30 \%$ of smectite and kaolinite). Additionally, hematite occurs in the GMF and chlorite in the Cergowa Beds, respectively. The macerals assemblage of the GMF is dominated by landplant-derived compounds of liptinite, associated with minor amounts of vitrinite representing type II kerogen. The total organic carbon (TOC) content is between 0.45 and $6.16 \mathrm{wt} . \%$. The $\delta^{13} \mathrm{C}_{\text {org }}$ values of the GMF vary between -27.1 and $-27.9 \%$. The values of both carbon and oxygen isotopic ratios of carbonates range for $\delta^{13} \mathrm{C}$ from -1.1 to $-4.3 \%$ VPDB, and for $\mathrm{O}$ from -1.5 to $-4.8 \%$ VPDB. The concentrations of $\mathrm{Co}, \mathrm{U}, \mathrm{Ni}$, As, and Mo are higher in the GMF than in the adjacent strata and positively correlate with TOC and S. Values of the TOC/S and V/V+Ni ratios are 0.7 to 3.5 and 0.67 to 0.78 , respectively, and indicate anoxic conditions. The ratios of $\mathrm{U} / \mathrm{Th}$ and $\mathrm{V} / \mathrm{Cr}(0.3-2.2,1.18-3.18$, respectively) suggest the change of oxic conditions to reducing conditions occurred during the GMF deposition. This change could have been preceded by a plankton bloom, initiated by a nutrient-rich freshwater inflow that is inferred from the decrease of the $\delta^{13} \mathrm{C}_{\text {carb }}$ values and the terrestrial detritus supply. Thermal alteration of the Grybów Succession is concluded on the basis of smectite illitisation and low $\delta^{18} \mathrm{O}$ values.
\end{abstract}

Key words: Paratethys, Oligocene, Grybów Succession, geochemistry, organic matter.

\section{INTRODUCTION}

The birth of an isolated Paratethys Sea started around the Eocene-Oligocene boundary (Báldi, 1980; Rusu, 1988), induced by tectonic activities along the Alpine front. The Turgai Strait closed and water flow from the North Sea led to a new oceanic circulation in the intercontinental Paratethys. The Paratethys was separated from the Mediterranean. Elongated deep troughs stretched from the Western Alps to the Transcaspian Basin (Rögl, 1999; Schulz et al., 2005).

The closure of the marine seaways culminated with the onset of the nannoplankton zone NP 23 (Lower Oligocene, i.e. Kiscellian as Central Paratethys stage, Rupelian - standard stage). Dysaerobic bottom conditions spread in the Paratethys basins and facilitated the sedimentation of organic matter (OM)-rich sediments (Popov et al., 1993; Rögl, 1999), extending from the Molasse Basin throughout the Carpathians to the Caspian Basin (Kotlarczyk, 1979; Vetö, 1987; Popov et al.,

\section{*E-mail: p.wojcik-tabol@uj.edu.pl}

Received: December 4, 2014; accepted: April 28, 2015; first published online: July 9, 2015
2004; Schulz et al., 2005; Sachsenhofer and Schulz, 2006). The OM-rich deposits are important source rocks for hydrocarbons in many places of the Paratethys region (e.g., Ziegler and Roure, 1999; Kotarba and Koltun, 2006).

More open, well-oxygenated marine bottom conditions prevailed in the middle part of the Oligocene (NP 24, lower Egerian in Central Paratethys, upper Rupelian-lower Chattian as standard stage). This corresponds with a period of clastic sediment and turbidite deposition in all Paratethys basins (Rögl, 1999).

The Oligocene organic-rich facies in the Polish Outer Carpathians is known as the Menilite Formation (Kotlarczyk and Leśniak, 1990). The aim of this study was to unveil the redox conditions and organic matter sources during the deposition of the Oligocene succession of the Grybów Nappe in its stratotype-locality in the Grybów tectonic window (GTW), in respect of its petrology and chemical composition. If anoxia had occupied the basin, the sediment deposited therein would have showed appropriate features. Several commonly accepted inorganic indices $(\mathrm{U} / \mathrm{Th}, \mathrm{V} / \mathrm{V}+\mathrm{Ni}, \mathrm{Ni} / \mathrm{Co}, \mathrm{TOC}$ - total organic carbon, TOC/S) were used in an attempt to interpret the redox conditions during the formation of the dark-coloured strata in the Grybów Nappe. The degree of illitisation of smectite, the thermal maturity of kerogen, and the stable isotopic compositions of carbonates were studied in order to investigate the alteration of sediments owing to high-temperature and diagenetic processes. 


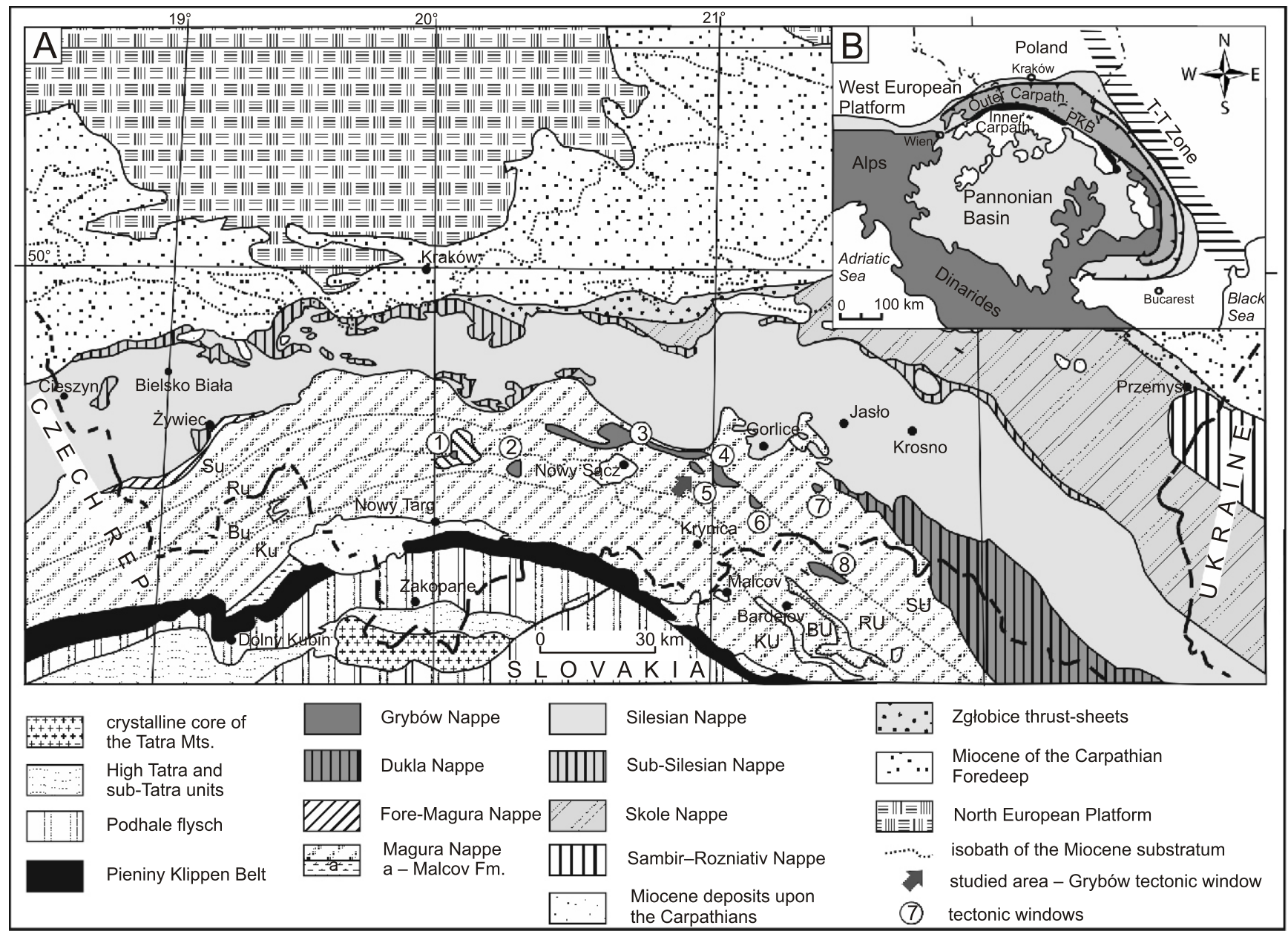

Fig. 1. Location of the study site

A - simplified geological map of the central part of the Polish Carpathians (after Żytko et al., 1989; Lexa et al., 2000, modified); B - schematic map of the East Alpine-Carpathian-Pannonian basin system (after Kovač et al., 1998, modified); PKB - Pieniny Klippen Belt; tectonic windows: 1 - Mszana Dolna, 2 - Szczawa, 3 - Klęczany-Pisarzowa, 4 - Ropa, 5 - Grybów, 6 - Uście Gorlickie, 7 - Swiątkowa Wielka, 8 Smilno; BU - Bystrica Slice, KU - Krynica Slice, RU - Rača Slice, SU - Siary Slice

\section{GEOLOGICAL FRAMEWORK AND SECTION STUDIED}

The Grybów Nappe (Świdziński, 1963), known also as Ropa-Pisarzowa Unit (Kozikowski, 1956), belongs to the Fore Magura Group of nappes of the Polish Outer Carpathians. The Grybów Nappe, consisting predominantly of Late EoceneOligocene deposits (Kozikowski, 1956; Sikora, 1960; Oszczypko-Clowes and Oszczypko, 2004; Oszczypko-Clowes and Ślączka, 2006; Oszczypko-Clowes, 2008; Oszczypko and Oszczypko-Clowes, 2011), is known from tectonic windows in the Magura Nappe (Fig.1; see also Książkiewicz, 1972). The GTW is located ca. $2 \mathrm{~km}$ south of the Magura Nappe front and $12 \mathrm{~km}$ east of Nowy Sącz (Fig. 1), between Grybów and Librantowa (Świdziński, 1963).

The Eocene of the Grybów Succession is represented by green, grey, and black shales, with intercalations of fine- to medium-grained glauconitic sandstones, known as the Hieroglyphic Beds (Sikora, 1960, 1970) or the Klęczany Beds (Kozikowski, 1956). The Upper Eocene greenish calcareous mudstones are equivalent to the Sub-Menilite Globigerina Marls, being a key-ho- rizon for all units of the Outer Carpathians (Olszewska, 1983; Oszczypko [Clowes], 1996; Leszczyński, 1997).

The Oligocene is represented by a series of $150 \mathrm{~m}$ thick green, grey, and brownish-black marls, and marly shales interbedded with thin- to medium-bedded, micaceous, and glauconitic sandstones assigned to the Sub-Grybów Beds (S-GB; Kozikowski, 1956). The S-GB turn into the Grybów Marl Formation (GMF; Oszczypko-Clowes and Ślączka, 2006), called also Grybów shales (Uhlig, 1888; Sikora, 1960) or Grybów Beds (Kozikowski, 1956), developed as a series up to $200 \mathrm{~m}$ thick black and brownish-black, platy-splitting marls with rare intercalations of grey marls and sandstone. Within the upper part of this series, thick lenses of ferruginous dolomites occur. Siliceous brown marls with cherts and hornstone layers appear in the highest part of the GMF (Figs. 2 and 3).

Upwards in the section there is a 200 m thick sequence of grey, calcareous shales and thin- to medium-bedded, micaceous sandstones, the so-called the Cergowa Beds (upper Oligocene; Ślączka, 1971; Koráb and Durkovič, 1978). The section up to $300 \mathrm{~m}$ along the southern tributary of the Strzylawka Stream exposes the transition of the GMF to the Cergowa Beds (Figs. 2 and 3). 


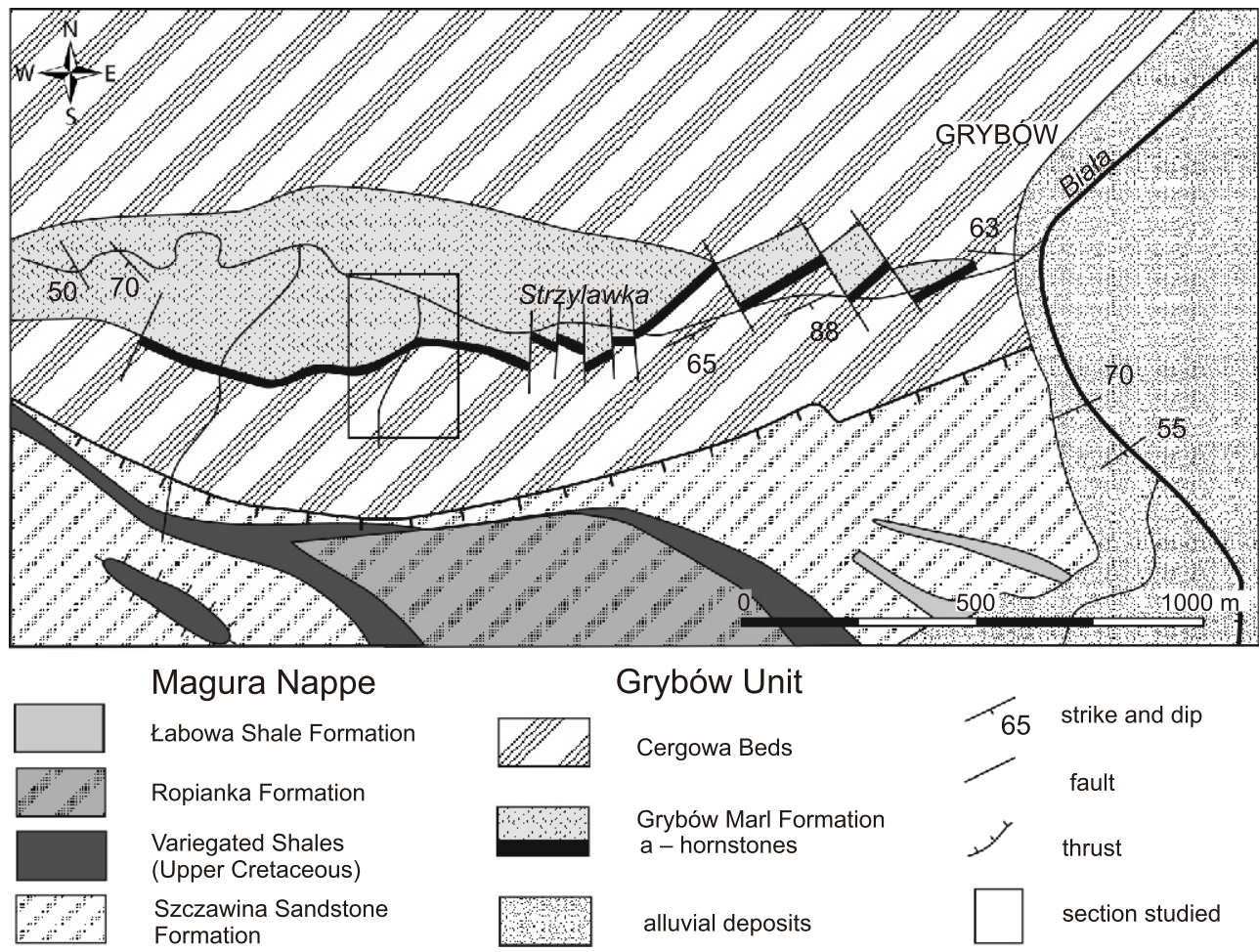

Fig. 2. Simplified geological map of the Grybów tectonic window (after Ślączka, 1971, modified)

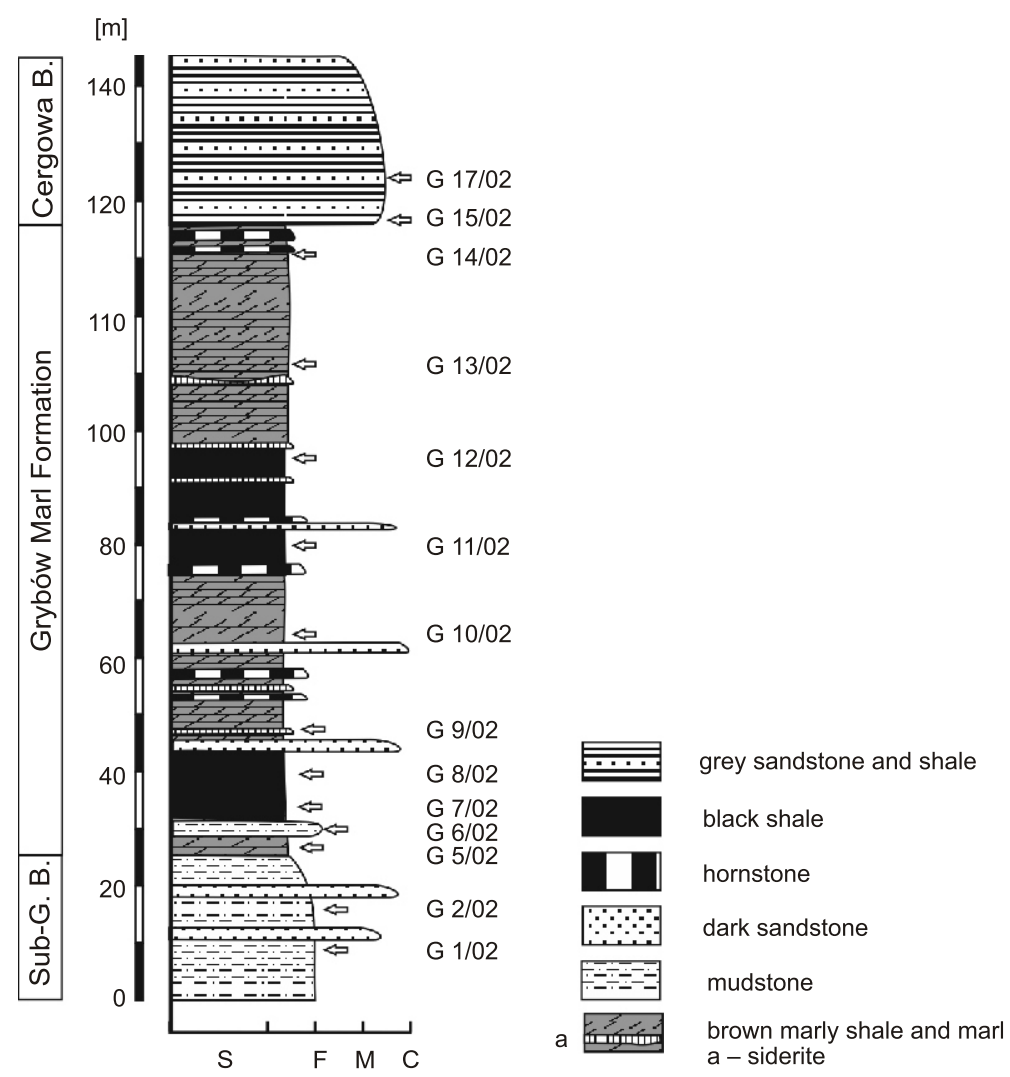

Fig. 3. Lithostratigraphic log through the Grybów Succession in the Grybów tectonic window with location of the samples collected

Sub-G. B. - Sub-Grybów Beds, Cergowa B. - Cergowa Beds; fraction: $\mathrm{S}$ - clay-silt, $\mathrm{F}$ - fine, $\mathrm{M}$ - medium, $\mathrm{C}$ - coarse 


\section{SAMPLES AND ANALYTICAL PROCEDURES}

The samples were collected by M. Oszczypko-Clowes and A. Ślączka during their field work in 2002. Eighteen samples of marl, shale, and mudstone were collected as representatives of the S-GB, GMF and Cergowa Beds.

Seven rock samples (one from the S-GB, four from the GMF, and two from the Cergowa Beds) differing in lithology and colour (black, brown, and grey) were chosen for mineralogical studies. The samples were hand-ground in an agate mortar. The mineral composition of all eight samples was determined by X-ray diffraction (XRD), using a Philips X'Pert $A P D$ diffractometer with a PW1870 generator and vertical goniometer $P W 3020$, equipped with a graphite diffraction beam monochromator. CuK $\alpha$ radiation was used with an applied voltage of $40 \mathrm{kV}$ and a $30 \mathrm{~mA}$ current. The mounts were scanned from 2 to $65^{\circ} 2 \theta$ at a counting speed of $0.02^{\circ}$ per $5 \mathrm{~s}$. Fractions of $<0.2 \mu \mathrm{m}$ and $<2 \mu \mathrm{m}$ were separated from four rock samples of the GMF, according to the Jackson procedure (Jackson, 1975). Carbonates, sulphates, and divalent exchangeable cations were removed by an acetic buffer. Organic matter was oxidised using a $30 \%$ hydrogen peroxide solution, whereas iron oxides were removed using sodium dithionite, according to the Mehra and Jackson (1960) procedure. The XRD data obtained for the oriented slides prepared from the separated fractions were recorded in air-dry conditions after saturation with ethylene glycol vapour and subsequent heating at 330 and $550^{\circ} \mathrm{C}$.

Petrology and microstructures were examined on thin sections using a Nikon-Eclipse $600 \mathrm{POL}$ polarized (transmitted and reflected) light microscope. Investigations under blue UV light were also performed. The fluorescence microscopy system is the Nikon-Eclipse 600 microscope, which is fitted with a 100 watt mercury lamp equipped with an excitation filter (EX 450-490 nm), dichroic mirror (DM $505 \mathrm{~nm}$ ), and barrier filter (BA $520 \mathrm{~nm}$ ).

In order to determine the type and quality of the organic matter contained within the samples, nine samples of brown and black shale and mudstone (two of S-GB and seven of GMF, see Table 1) were analysed by pyrolysis at the Petrogeo Laboratory, Kraków. Pyrolysis by Rock-Eval technique was car- ried out with a Rock-Eval Model II instrument equipped with an organic carbon module (for analytical details, see Espitalié et al. 1985; Espitalié and Bordenave, 1993).

Stable carbon isotopes were analysed in the same samples (Table 1). The analysis was conducted using Finnigan Delta-V equipment. The $\delta^{13} \mathrm{C}$ values were normalized to NBS-22 and USGS-24 international standards and then reported to the international Pee Dee Belemnite (VPDB) scale (Coplen et al., 2006). The analytical precision was $\pm 0.03 \%$.

Nine calcareous samples were also analysed for stable isotope $\delta^{13} \mathrm{C}(\mathrm{DIC})$ and $\delta^{18} \mathrm{O}$. Carbon dioxide was released by reaction of $20 \mathrm{ml}$ of water sample with $0.5 \mathrm{ml}$ of $\mathrm{H}_{3} \mathrm{PO}_{4}$ on vacuum line and then cryogenically purified for off-line analyses in a Finnigan-Mat Delta E/dual inlet. All $\delta^{13} \mathrm{C}$ values were presented relative to the scale VPDB with $\pm 0.10 \%$ o precision. The isotopic analyses were carried out in the Laboratory of Isotope Geology and Geoecology at Wrockaw University.

Eight samples (one from S-GB, five from GMF, and two from the Cergowa Beds, see Table 2) were selected for inorganic geochemical analysis. Samples were analysed for 11 major oxides $\left(\mathrm{SiO}_{2}, \mathrm{Al}_{2} \mathrm{O}_{3}, \mathrm{Fe}_{2} \mathrm{O}_{3}, \mathrm{MgO}, \mathrm{CaO}, \mathrm{Na}_{2} \mathrm{O}, \mathrm{K}_{2} \mathrm{O}, \mathrm{TiO}_{2}\right.$, $\mathrm{P}_{2} \mathrm{O}_{5}, \mathrm{MnO}, \mathrm{Cr}_{2} \mathrm{O}_{3}$ ) and 45 refractory and Rare Earth Elements by inductively-coupled plasma-mass spectrometry (ICP-MS) using a Perkin Elmer Elan 6000 and ICP with atomic emission spectrometry (ICP-AES) at the ACME Analytical Laboratories, Ltd., in Vancouver, Canada. Sample pulp (2 mg in weight) was prepared by fusing the sample with $1.5 \mathrm{~g}$ of lithium borate in a graphite crucible, and then heating at $980^{\circ} \mathrm{C}$ for 30 minutes. The molten mixture was poured into $100 \mathrm{ml}$ of $5 \% \mathrm{HNO}_{3}$. A second $0.5 \mathrm{~g}$ split sample was digested in Aqua Regia and analysed by ICP-MS to determine Ag, As, $\mathrm{Au}, \mathrm{Bi}, \mathrm{Cd}, \mathrm{Cu}, \mathrm{Hg}, \mathrm{Mo}$, $\mathrm{Ni}, \mathrm{Pb}, \mathrm{Sb}, \mathrm{Se}, \mathrm{TI}$, and $\mathrm{Zn}$. The loss on ignition (LOI) was estimated by the weight difference after ignition at $1,000^{\circ} \mathrm{C}$.

The chemical data obtained for major and selected trace elements are shown in Table 2. Concentrations of the trace elements are normalized relative to aluminium to compensate for dilution or concentration by phyllosilicates. The elements were normalized relative to standards i.e. average shale (Wedepohl, 1971) as representative of shallow-water sediments accumulated under oxidizing conditions.

Rock-Eval pyrolysis data and stable isotopic composition $\left(\delta^{13} \mathrm{C}_{\text {org. }}\right.$ of organic matter, $\delta^{13} \mathrm{C}_{\text {carb. }}$ and $\delta^{18} \mathrm{O}_{\text {carb. of carbonates })}$ for selected samples of the Grybów Succession, nannoplankton zones (NP 24 and NP 25) after Oszczypko-Clowes and Ślączka (2006)

\begin{tabular}{|c|c|c|c|c|c|c|c|c|c|c|c|c|}
\hline & \multirow{2}{*}{\multicolumn{2}{|c|}{ Sub-G. Beds }} & \multicolumn{9}{|c|}{ Grybów Marl Fm. } & \multirow{3}{*}{$\begin{array}{c}\text { Cergowa B. } \\
\text { NP } 25 \\
\text { G } 17 / 02\end{array}$} \\
\hline & & & & & NP 24 & NP 24 & NP 24 & NP 24 & NP 24 & NP 24 & & \\
\hline & G 1/02 & G 2/02 & G 5/02 & G 6/02 & G 7/02 & G 8/02 & G 9/02 & G 10/02 & G 11/02 & G 12/02 & G 13/02 & \\
\hline$T_{\max }\left[{ }^{\circ} \mathrm{C}\right]$ & 440 & 441 & 441 & 444 & 444 & 446 & nd. & 446 & 444 & 442 & nd. & nd. \\
\hline $\mathrm{S} 1[\mathrm{mg} / \mathrm{g}]$ & 0.4 & 0.31 & 1.05 & 0.7 & 1.55 & 0.45 & nd. & 0.52 & 1.04 & 0.61 & nd. & nd. \\
\hline $\mathrm{S} 2$ [mg/g] & 0.67 & 1.27 & 8.74 & 3.68 & 10.34 & 1.2 & nd. & 1.85 & 7.53 & 5.17 & nd. & nd. \\
\hline S3 [mg/g] & 0.6 & 0.34 & 0.55 & 0.42 & 1.41 & 1.17 & nd. & 0.72 & 0.57 & 0.81 & nd. & nd. \\
\hline TOC [wt.\%] & 0.45 & 0.69 & 3.64 & 0.65 & 6.16 & 1.26 & nd. & 0.64 & 3.9 & 2.89 & nd. & nd. \\
\hline $\mathrm{HI}$ [mg HC/g TOC] & 148 & 184 & 240 & 556 & 167 & 95 & nd. & 286 & 193 & 180 & nd. & nd. \\
\hline $\mathrm{OI}[\mathrm{mg} \mathrm{CO} / \mathrm{g}$ TOC] & 133 & 49 & 15 & 64 & 22 & 92 & nd. & 112 & 14 & 28 & nd. & nd. \\
\hline$\delta^{13} \mathrm{C}_{\text {org. }}[\% 0]$ & nd. & -27.9 & -27.8 & -27.1 & -27.4 & -27.5 & nd. & -27.4 & -27.4 & -27.7 & nd. & nd. \\
\hline$\delta^{13} \mathrm{C}_{\text {carb. }}[\%$ o] & -1.3 & nd. & -2.3 & nd. & -3.4 & nd. & -3.1 & -1.1 & -4.3 & -1.3 & -1.7 & -1.7 \\
\hline$\delta^{18} \mathrm{O}_{\text {carb. }}[\% o]$ & -1.5 & nd. & -2.9 & nd. & -3.5 & nd. & -3.7 & -2.6 & -4.8 & -2.7 & -4.8 & -2.6 \\
\hline
\end{tabular}


Chemical composition of the Grybów Succession samples, nannoplankton zones (NP 24 and NP 25) after Oszczypko-Clowes and Ślączka (2006)

\begin{tabular}{|c|c|c|c|c|c|c|c|c|c|c|}
\hline & \multirow{2}{*}{\multicolumn{2}{|c|}{ Grybów Marl Fm. }} & \multicolumn{7}{|c|}{ Cergowa Beds } & \multirow{3}{*}{ av.sh. } \\
\hline & & & & NP 24 & NP 24 & NP 24 & NP 24 & NP 24 & NP 25 & \\
\hline & DL & G 1/02 & G 5/02 & G 7/02 & G 8/02 & G 10/02 & G 11/02 & G 15/02 & G $17 / 02$ & \\
\hline $\mathrm{SiO}_{2}[\%]$ & 0.01 & 40.7 & 34.9 & 45.7 & 40.3 & 29.4 & 41.2 & 40.6 & 43.4 & 58.9 \\
\hline $\mathrm{Al}_{2} \mathrm{O}_{3}[\%]$ & 0.01 & 12.2 & 11.5 & 12.5 & 12.0 & 10.7 & 11.2 & 11.3 & 10.4 & 16.7 \\
\hline $\mathrm{Fe}_{2} \mathrm{O}_{3}[\%]$ & 0.04 & 4.9 & 5.5 & 6.6 & 6.0 & 3.5 & 4.7 & 4.4 & 4.2 & 6.9 \\
\hline $\mathrm{MgO}[\%]$ & 0.01 & 4.0 & 1.1 & 1.2 & 1.8 & 1.2 & 1.2 & 2.3 & 3.0 & 2.6 \\
\hline $\mathrm{CaO}[\%]$ & 0.01 & 14.5 & 20.4 & 10.6 & 16.6 & 26.2 & 16.6 & 17.8 & 16.4 & 2.2 \\
\hline $\mathrm{Na}_{2} \mathrm{O}[\%]$ & 0.01 & 0.6 & 0.5 & 0.7 & 0.8 & 0.4 & 0.6 & 0.6 & 0.8 & 1.6 \\
\hline $\mathrm{K}_{2} \mathrm{O}[\%]$ & 0.01 & 2.4 & 1.9 & 2.4 & 2.4 & 1.7 & 2.2 & 2.3 & 2.0 & 3.6 \\
\hline $\mathrm{TiO}_{2}[\%]$ & 0.01 & 0.53 & 0.50 & 0.64 & 0.55 & 0.47 & 0.50 & 0.52 & 0.51 & 0.78 \\
\hline $\mathrm{P}_{2} \mathrm{O}_{5}[\%]$ & 0.01 & 0.11 & 0.13 & 0.24 & 0.13 & 0.10 & 0.19 & 0.12 & 0.10 & 0.16 \\
\hline $\mathrm{MnO}[\%]$ & 0.01 & 0.15 & 0.06 & 0.07 & 0.27 & 0.11 & 0.04 & 0.11 & 0.10 & 0.11 \\
\hline LOI [\%] & -5.1 & 19.7 & 23.2 & 19.1 & 19.1 & 26.1 & 21.4 & 19.8 & 18.9 & \\
\hline Co [ppm] & 0.2 & 11.8 & 31.2 & 24.2 & 28.0 & 14.2 & 15.0 & 12.0 & 13.2 & 19.0 \\
\hline $\mathrm{Hf}[\mathrm{ppm}]$ & 0.1 & 2.5 & 2.2 & 4.1 & 2.5 & 2.3 & 2.6 & 2.5 & 3.5 & \\
\hline Th [ppm] & 0.2 & 9.2 & 8.7 & 9.8 & 8.9 & 7.8 & 7.8 & 8.8 & 7.8 & \\
\hline U [ppm] & 0.1 & 3.2 & 19.3 & 13.1 & 5.8 & 6.4 & 9.6 & 2.5 & 2.3 & 3.7 \\
\hline V [ppm] & 8 & 124 & 335 & 286 & 156 & 148 & 288 & 118 & 101 & 130 \\
\hline $\mathrm{Zr}$ [ppm] & 0.1 & 89.3 & 88.3 & 148.7 & 93.6 & 86.5 & 94.5 & 90.3 & 131.2 & 160.0 \\
\hline TOT/S [\%] & 0.02 & 0.41 & 2.52 & 1.77 & 0.69 & 0.91 & 1.15 & 0.20 & 0.24 & 0.20 \\
\hline Mo [ppm] & 0.1 & 0.70 & 31.60 & 12.30 & 3.80 & 5.20 & 15.50 & 0.70 & 1.00 & 1.00 \\
\hline $\mathrm{Ni}$ [ppm] & 0.1 & 38.4 & 133.3 & 93.8 & 76.3 & 52.6 & 77.7 & 37.7 & 43.1 & 68.0 \\
\hline As [ppm] & 0.5 & 5.2 & 37.4 & 45.0 & 16.0 & 16.0 & 19.4 & 5.8 & 7.2 & 10.0 \\
\hline U/Th & & 0.35 & 2.22 & 1.34 & 0.65 & 0.82 & 1.23 & 0.28 & 0.29 & \\
\hline $\mathrm{V} / \mathrm{Cr}$ & & 1.57 & 3.18 & 2.17 & 1.69 & 1.87 & 2.43 & 1.38 & 1.18 & \\
\hline $\mathrm{V} / \mathrm{V}+\mathrm{Ni}$ & & 0.76 & 0.72 & 0.75 & 0.67 & 0.74 & 0.79 & 0.76 & 0.70 & \\
\hline $\mathrm{Ni} / \mathrm{Co}$ & & 3.25 & 4.27 & 3.88 & 2.73 & 3.70 & 5.18 & 3.14 & 3.27 & \\
\hline $\mathrm{C} / \mathrm{S}$ & & 1.10 & 1.44 & 3.48 & 1.83 & 0.70 & 3.39 & & & \\
\hline
\end{tabular}

DL - detection limit, av. sh. - average shale composition after Wedepohl (1971)

\section{RESULTS}

\section{MINERAL COMPOSITION}

Material studied from the S-GB, GMF, and Cergowa Beds is represented by calcareous, fine-grained mudstones and shales. XRD patterns of the seven chosen samples show the presence of quartz, calcite, Na-rich plagioclase, muscovite, and clay minerals (illite-smectite and kaolinite; Fig. 4). Some of the samples (G 1/02, G 15/02, G 17/02) show weak dolomite peaks. Additionally, the GMF is characterized by the presence of hematite. No chlorite was found there (Fig. 4A), whereas in the Cergowa Beds, no hematite was found and chlorite becomes apparent (Fig. 4B).

XRD data obtained for the $<0.2 \mu \mathrm{m}$ fractions of GMF indicate clay mineral assemblages including illite, mixed-layered illite-smectite, and kaolinite. The percentage of smectite in the I/S ranges from 25 to $30 \%$ (Fig. $4 \mathrm{C}$ ).

The brown marls are composed mainly of a reddish matrix with dispersed silt-sized grains of quartz, mica, and small foraminiferids (Fig. 5A). The dark matrix consists of carbonates and randomly oriented clay minerals lamellae admixed with extremely fine-grained Fe oxyhydroxides and organic matter. The quartz grains are sub-angular and corroded. Foraminifer tests are replaced by calcite. Many specimens reveal internal filling with black organic matter.

The mudstone samples (G 10/02 and G 17/02) consist of a matrix cementing fine-grained quartz, muscovite, plagioclase, glauconite, organic debris, and heavy minerals. There is an obviously preferred orientation of mica and agglomeration of OM in an elongated form. The matrix consists of clay minerals and carbonates, locally pigmented by Fe oxyhydroxides and organic matter (Fig. 5G). Laminae are a typical sedimentary feature. They exhibit a wide range in thickness and types (even, discontinuous, lenticular or wrinkled). The internal lamina features include sharp basal contacts and transitional top contacts. The laminae are distinguishable due to their changing fractions and colour. Rhombohedra of carbonate minerals are abundant in the Cergowa Beds (Fig. 5F).

ORGANIC PETROLOGY - MACERALS EXAMINATION

The dark brown and black samples of the GMF contain an abundant maceral assemblage that is dominated by landplant-derived compounds of liptinite groups associated with minor amounts of vitrinite and intertynite. 

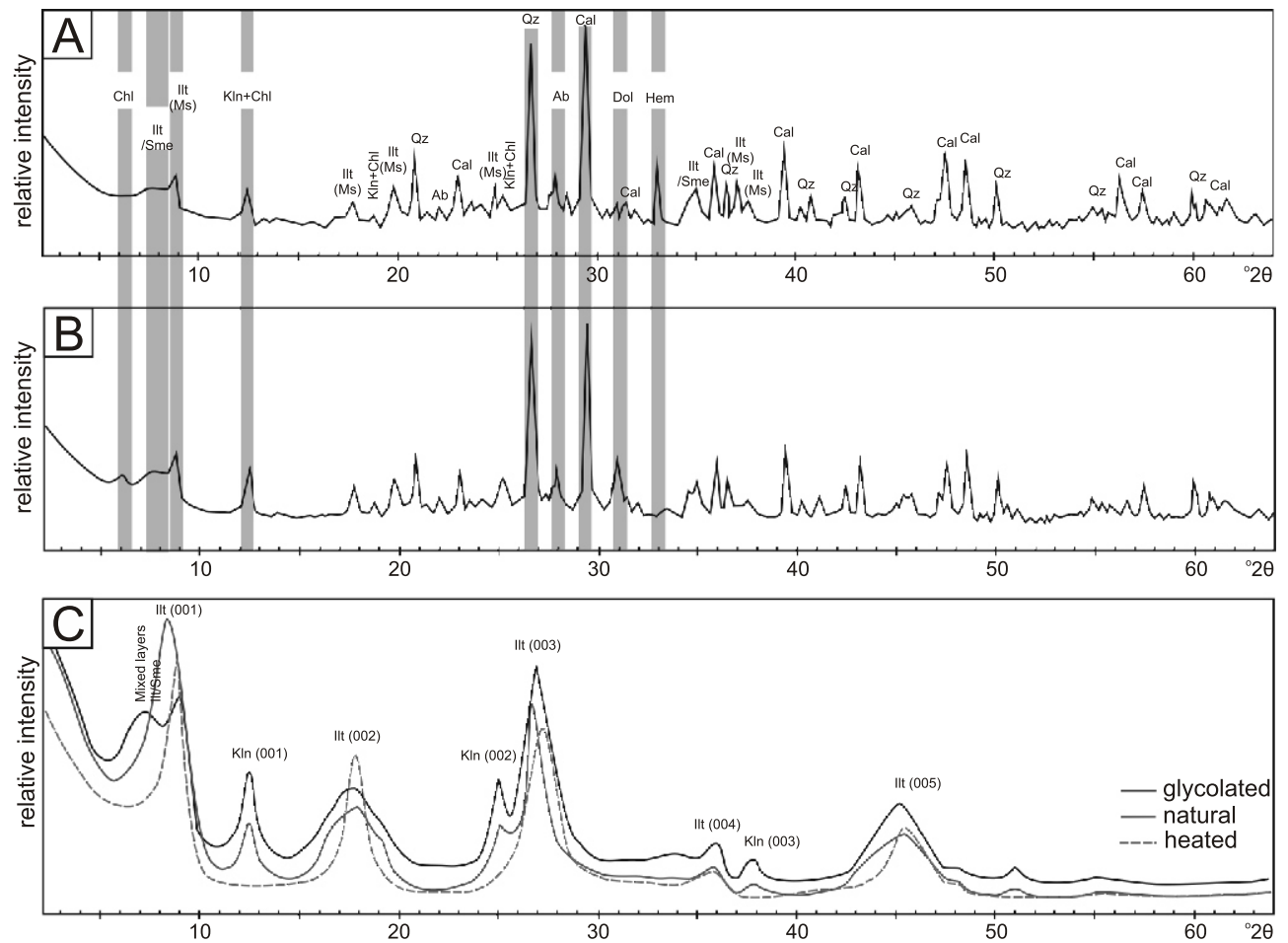

Fig. 4. XRD patterns of the whole-rock samples: A - brown marl of GMF; B - olive shale of Cergowa Beds, the most intense peaks of the main minerals are marked; C - XRD diffractogram for untreated, heated, and glycolated of clay separates from the Grybów Marl Formation sample

$\mathrm{Ab}$ - albite, Cal - calcite, Chl - chlorite, Dol - dolomite, Hem - hematite, Ilt/Sme - illite/smectite, KIn - kaolinite, Ms - muscovite, Qz - quartz (abbreviation according to IMA, Whitney and Evans, 2010)
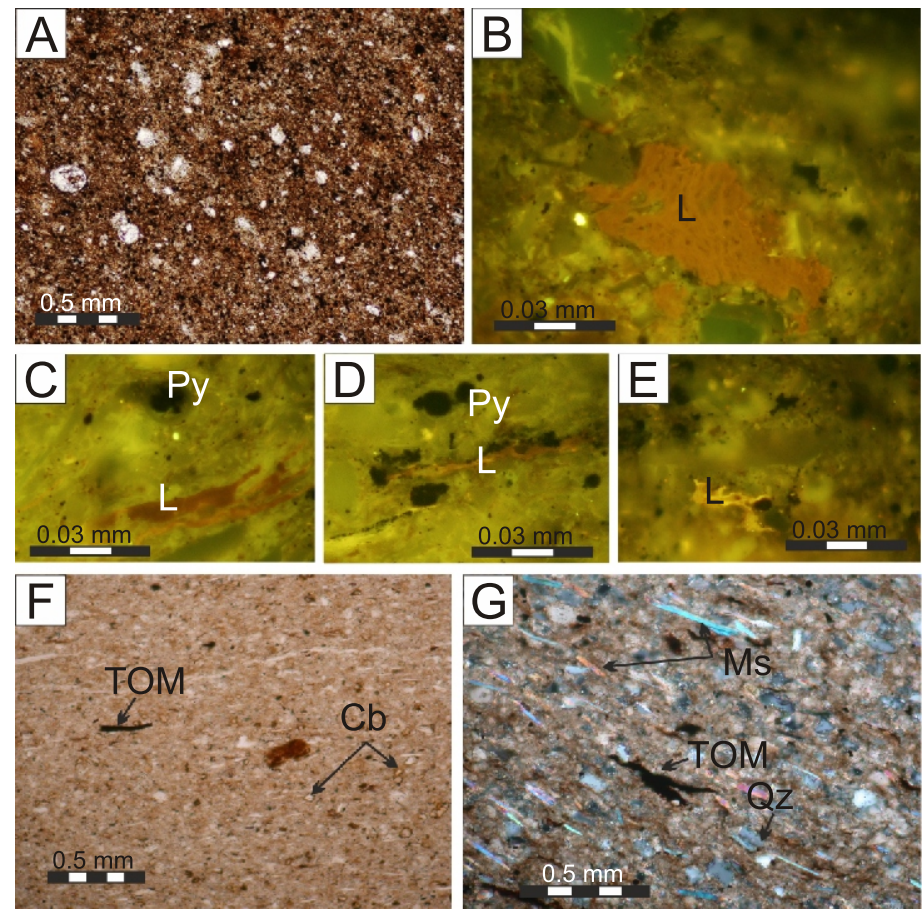

Fig. 5. Polarized (transmitted) light photomicrographs: Abrown marl of the GMF with a matrix, pigmented by $\mathrm{Fe}$ oxyhydroxides and organic matter, in which mineral detritus and foraminifera tests are dispersed, one polarizer; B-E - liptinite macerals and pyrite grains in the GMF brown marl, UV blue illumination; F, G - mudstone from the Cergowa Beds; one polarizer (F) and crossed polarizers (G)

$\mathrm{Cb}$ - carbonate minerals, Glt - glauconite, $\mathrm{HM}$ - heavy minerals, Ms - muscovite, Py - pyrite, Qz - quartz (mineral abbreviations according to Whitney and Evans, 2010); L - liptinite, TOM - terrigenous organic matter 


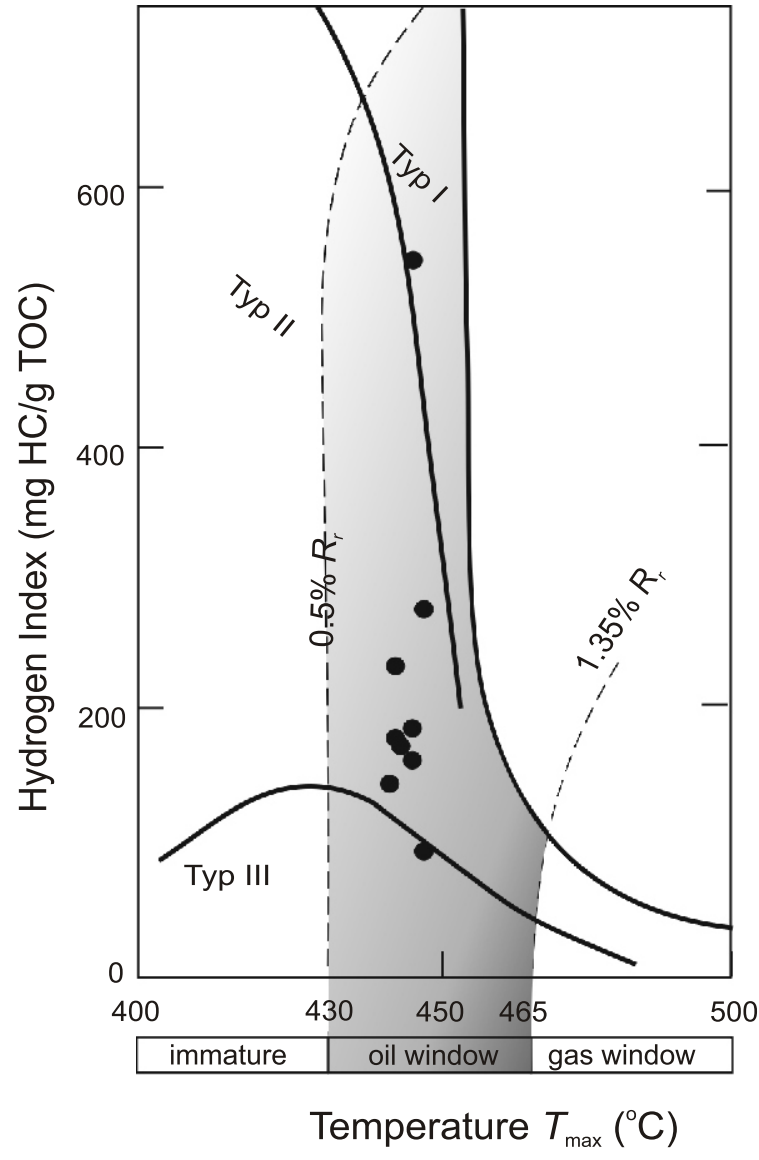

Fig. 6. Discriminant crossplot of $H I$ vs. $T_{\max }$ for organic maturity and kerogen type

Maturity paths of individual kerogen types after Espitalié et al. (1985); $R_{r}$ - vitrinite reflectance scale

The brown marls contain elongated, fibrous (10-20 $\mu \mathrm{m}$ long), and loop-like OM which reveals orange and yellow luminescence in blue light (Fig. 5B-E). They represent a group of the liptinite macerals. Alginite occurrence was recognized in the samples G 5/02 and G 10/02. Grains of black debris, $50-100 \mu \mathrm{m}$ across up to $500 \mu \mathrm{m}$ in length, often with internal structure and white reflectance, are common (Fig. 5F, G).

The mudstone samples richer in mineral detritus are also enriched in the organic debris of vitrinite and inertinite. The organic matter is commonly accompanied by pyrite in various forms, e.g., framboids, individual crystals, and agglomerates. The framboids have a diameter ranging from 3 to $15 \mu \mathrm{m}$. The crystals are $5-10 \mu \mathrm{m}$ in size, and the massive lumps reach up to $100 \mu \mathrm{m}$ in diameter.

\section{ROCK EVAL PYROLYSIS INDICES}

The total organic carbon content of the samples studied is $0.45-6.16$ wt. $\%$. The highest values of TOC were obtained for the brownish-black marly shales, whereas the lowest organic carbon contents (<0.5 wt. \% TOC) were obtained from the grey and olive-green samples (Table 1).

The $T_{\max }$ values range from 440 to $446^{\circ} \mathrm{C}$ within the GMF. In the $T_{\max }$ Vs. $H I$ diagram (Fig. 6), the samples plot in the field of mature (oil-prone) Type II kerogen, with various additions of type III. Certain contributions of Type I kerogen is recognized in some samples (G 5/02, G 6/02, G 10/02) with higher $H$ ( 200 mg HC/g TOC)

\section{STABLE ISOTOPE COMPOSITION OF ORGANIC MATTER AND CARBONATES}

The organic carbon isotopic ratios $\left(\delta^{13} \mathrm{C}_{\text {org }}\right)$ in the GTW samples weakly vary between -27.1 and $-27.9 \%$ (Table 1 and Fig. 7A). The measured $\delta^{13} \mathrm{C}_{\text {org }}$ values reflect the nature of organic matter producers, i.e. the prevalence of terrestrial $(-27 \%)$ over marine organic material $(-22 \%$; Meyers, 1994). No relationship is observed between the $\delta^{13} \mathrm{C}_{\text {org }}$ values and $H I$ and TOC (Fig. 7B).

The values of both carbon and the oxygen isotopic ratios of carbonates show relatively wide ranges: $\delta^{13} \mathrm{C}-1.1$ to $-4.3 \%$ VPDB and $O$ from -1.5 to $-4.8 \%$ VPDB. The trends in both stable isotope compositions are parallel. The values decrease upwards in the section studied. A positive excursion is noted in the upper part of the GMF (sample G 10/02). A shift of $\delta^{13} \mathrm{C}_{\text {carb }}$ and $\mathrm{O}$ towards higher $\mathrm{C}$ and $\mathrm{O}$ isotope ratios of carbonates typifies the Cergowa Beds (Fig. 7A).

\section{MAJOR OXIDES}

Due to the calcareous nature of the Grybów Unit samples, the amounts of other major oxides measured are lower than those of average shales. The grey and light brown samples ( $G$ 1/02, G 15/02, G 17/02) are enriched in $\mathrm{MgO}$, the siliceous black shales ( $\mathrm{G} 7 / 02$ ) are rich in $\mathrm{Fe}_{2} \mathrm{O}_{3}$ and $\mathrm{P}_{2} \mathrm{O}_{5}$, and the brown
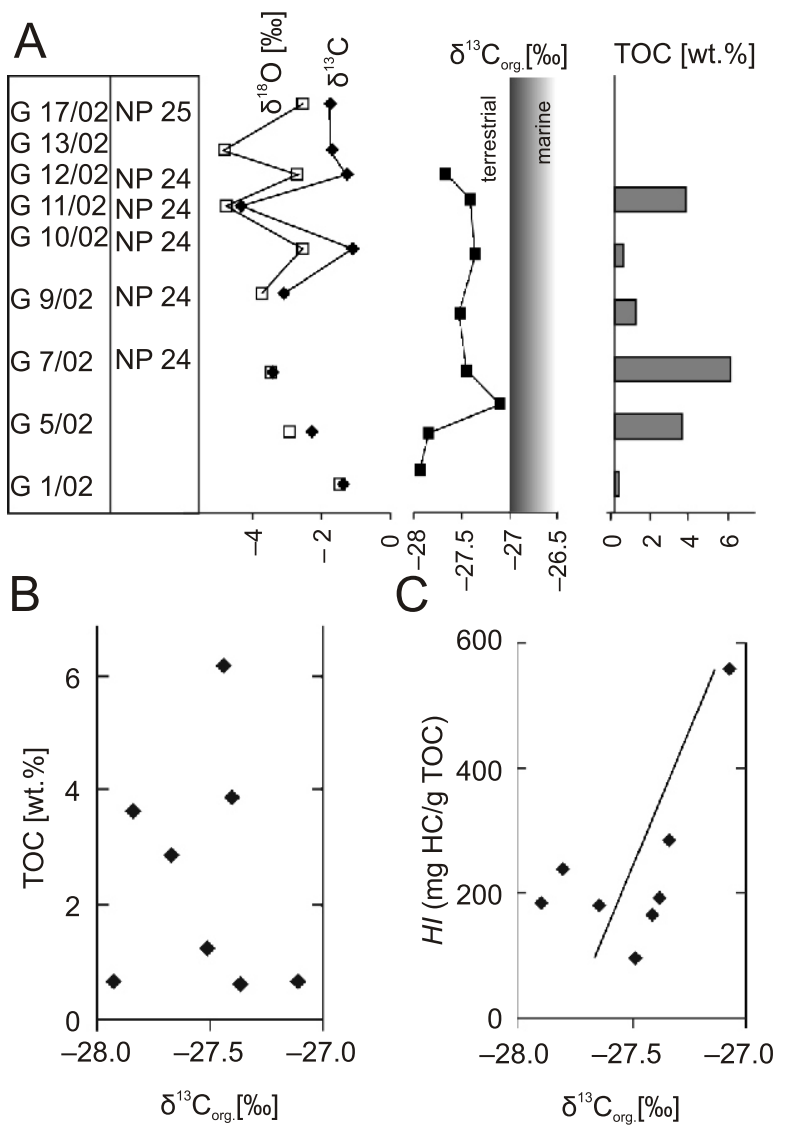

Fig. 7. Stable isotopic composition: A - stratigraphic variation of $\delta^{13} \mathrm{C}$ and $\delta^{18} \mathrm{O}$ in carbonates, $\delta^{13} \mathrm{C}_{\text {org }}$ and TOC; B, C correlation between $\delta^{13} \mathrm{C}_{\text {org }}$ and Rock-Eval indices (TOC and $H I$ ) 

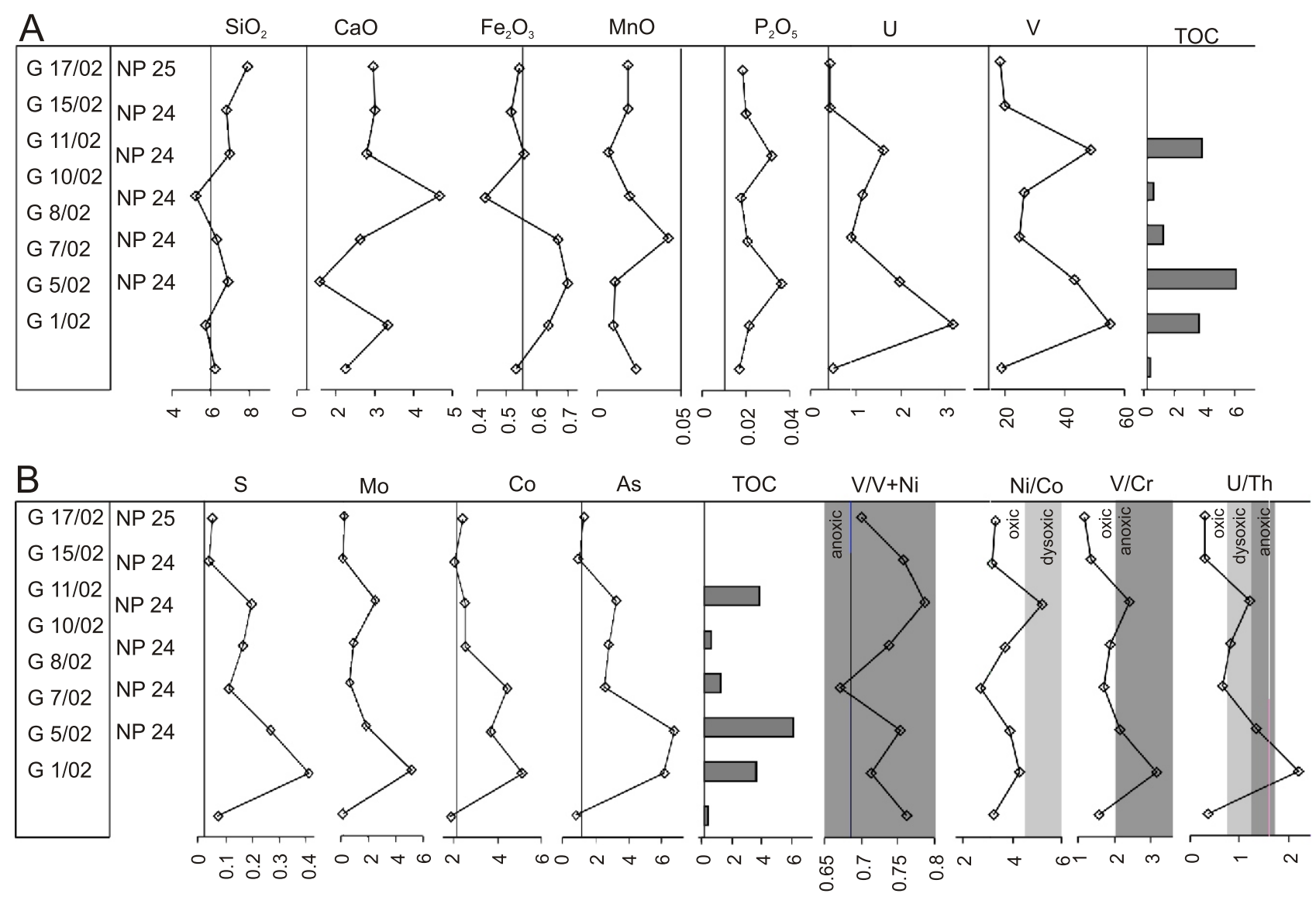

Fig. 8. Stratigraphic variation of major oxides and selected trace elements (A) and redox geochemical proxies (B) in the Oligocene strata studied

marls (G 8/02) contain more $\mathrm{Fe}_{2} \mathrm{O}_{3}$ and $\mathrm{MnO}$ (Table 2 and Fig. 8A).

There is a strong positive correlation between $\mathrm{Al}_{2} \mathrm{O}_{3}$ and $\mathrm{K}_{2} \mathrm{O}$, and $\mathrm{TiO}_{2}$ and $\mathrm{Th}$ (Fig. $9 \mathrm{~A}-\mathrm{C}$ ). High concentrations in these elements occur in the CaO-poor samples (G 1/02, G 7/02, $\mathrm{G}$ 8/02). $\mathrm{SiO}_{2}$ distribution through the section is parallel to $\mathrm{Zr}$ (Fig. 9D) and Hf, reaching maximal concentrations in samples G 7/02 and G 17/02 (Table 2).

\section{REDOX-SENSITIVE TRACE ELEMENTS (RSTE)}

The trace elements considered here as palaeoredox proxies are: $\mathrm{U}, \mathrm{Mo}, \mathrm{V}, \mathrm{Ni}, \mathrm{Co}, \mathrm{As}$, and $\mathrm{Cr}$. Redox-sensitive elements tend to be less soluble under reducing conditions, resulting in authigenic precipitation in anaerobic deposits. Some trace metals are associated with organic matter and/or pyrite (Breit and Wanty, 1991; Huerta-Diaz and Morse, 1992; Morford et al., 2005).

The variation of RSTE content normalized to $\mathrm{Al}$ is presented in Figure 8A, B. All the samples studied are more enriched in $\mathrm{Cr}$ and $\mathrm{V}$ than is average shale. The distributions of $\mathrm{Co} / \mathrm{Al}, \mathrm{U} / \mathrm{Al}$, $\mathrm{Ni} / \mathrm{Al}, \mathrm{As} / \mathrm{Al}$, and $\mathrm{Mo} / \mathrm{Al}$ in the grey and light brown samples ( $G 1 / 02, G 15 / 02$, and $G 17 / 02$ ) are comparable to that of average shale. The concentration of $\mathrm{Co}, \mathrm{U}, \mathrm{Ni}, \mathrm{As}$, and $\mathrm{Mo}$ increases in the black and brownish samples of the GMF (G 5/02, G 7/02, G 8/02, G 10/02, and G 11/02). The contents of Ni, V, $\mathrm{Co}, \mathrm{U}, \mathrm{As}$, and Mo are correlative with each other and correlative with $S$ and TOC (Fig. 8A, B). The TOC/S ratios calculated for the Oligocene samples vary from 0.7 to 3.48 .
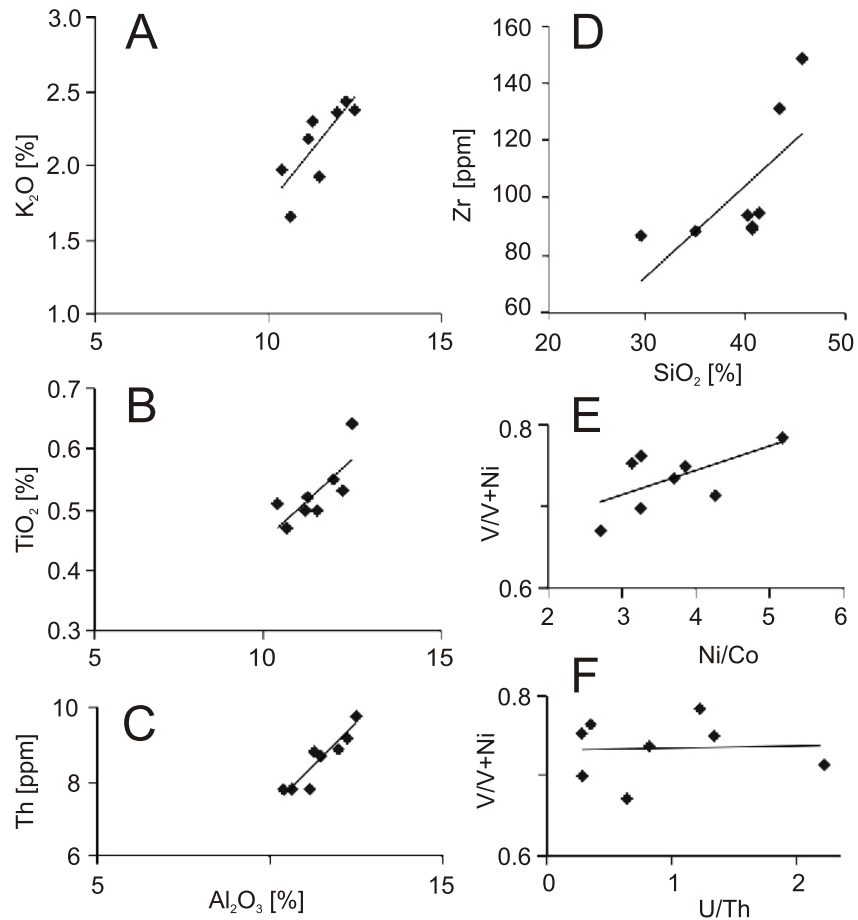

Fig. 9. Variation diagrams for major oxides and trace elements in the Oligocene strata studied: $\mathrm{A}-\mathrm{Al}_{2} \mathrm{O}_{3}$ vs. $\mathrm{K}_{2} \mathrm{O}$; $\mathrm{B}$ $-\mathrm{Al}_{2} \mathrm{O}_{3}$ vs. $\mathrm{TiO}_{2} ; \mathrm{C}-\mathrm{Al}_{2} \mathrm{O}_{3}$ vs. Th; $\mathrm{D}-\mathrm{SiO}_{2}$ vs. $\mathrm{Zr} ; \mathrm{E}-\mathrm{V} / \mathrm{V}+\mathrm{Ni}$ vs. $\mathrm{Ni} / \mathrm{Co} ; \mathrm{F}-\mathrm{V} / \mathrm{V}+\mathrm{Ni}$ vs. U/Th 


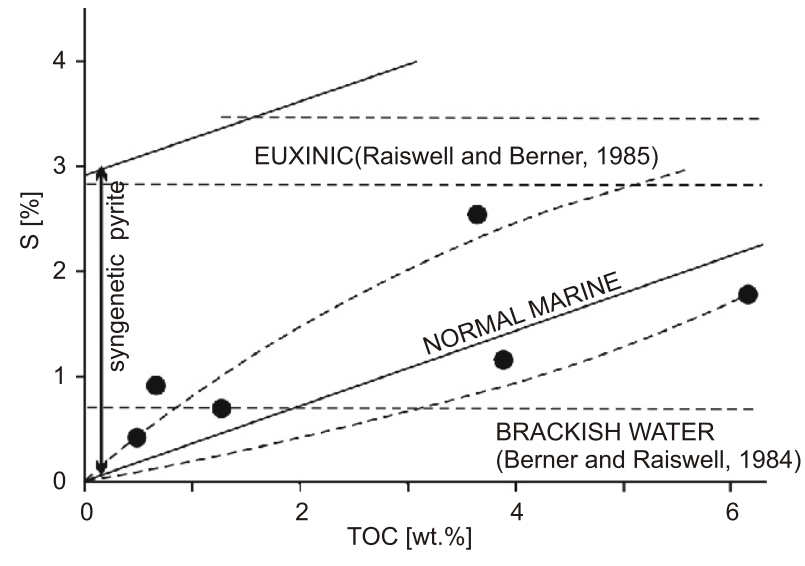

Fig. 10. Plot of some samples of the Grybów Succession within the organic carbon vs. sulphur variation diagram of Wignall (1994)

The trace element ratios are commonly used to describe the palaeoredox conditions. Critical ranges and cut-off values were adopted from Hatch and Leventhal (1992) for the V/V+N ratio and from Jones and Manning (1994) for the $\mathrm{V} / \mathrm{Cr}$, Ni/Co, and $\mathrm{U} / \mathrm{Th}$ ratios. $\mathrm{V} / \mathrm{N}+\mathrm{Ni}$ range from 0.67 to 0.78 in the samples studied. The $\mathrm{U} / \mathrm{Th}$ ratio is 0.3 in the light-coloured samples and $0.7-2.2$ in OM-rich samples. The V/Cr ratios vary from 1.18 to 3.18 with $\mathrm{V} / \mathrm{Cr}$ passing 2 in the OM-rich samples of the GMF (G 5/02, G 7/02, and G 11/02; Table 2 and Fig. 8B). The samples studied are described by $\mathrm{Ni} / \mathrm{Co}$ ratios ranging from 2.7 to 5.2 (Table 2 and Fig. 8B). The diagram of Ni/Co vs. V/V+Ni (Fig. 9E) shows positive correlation between proxies. U/Th vs. $\mathrm{V} / \mathrm{V}+\mathrm{Ni}$ (Fig. 9F) plots a flat relation between indices.

\section{DISCUSSION}

\section{ORIGIN AND PRESERVATION OF ORGANIC MATTER}

The brown marly shales (samples G 5/02, G 6/02 and G 10/02) contain liptinite macerals, derived mainly from the waxy and resinous parts of plants. A special type of liptinite is alginite consisting of organic-walled marine microfossils. Alginite occurrence was recognized in samples G 5/02 and G 10/02.

The mudstone samples (samples G 1/02, G 7/02, G 8/02, and $G 11 / 02$ ) richer in mineral detritus are concomitantly enriched in vitrinite and inertinite macerals. Vitrinite macerals comprising tellinite and collinite (according to Stopes, 1935) are derived from the cell wall material (woody tissues) of plants. Inertinite macerals are formed from plant material transformed by intense degradation. Liptinite macerals with trace to minor amounts of vitrinite and inertinite are components of types I and II kerogen. The vitrinite group is the chemical equivalent of type III kerogen. Inertinite represents oxidized and hydrogen-poor type IV kerogen (Peters and Moldowan, 1993).

Kerogen dominating in the Oligocene studied material represents type II, which originates from mixtures of zooplankton, phytoplankton, bacterial bodies, and the outer coatings of pollen, spores, and leaves. Type II kerogen is often accompanied by type III, derived mostly from higher plants (samples $\mathrm{G} 1 / 02$, G 2/02, G 7/02, G 8/02, G 11/02 and G 12/02). Type I kerogen presents occasionally ( $G / 02)$, and is predominately composed of the most hydrogen-rich organic matter of algal or bacterial origin (Peters and Moldowan, 1993).
Maceral studies and pyrolysis data show the terrestrial nature of organic matter in the materials studied. The contribution of marine organic matter cannot be excluded for the more pelagic samples of the GMF (G 5/02, G 6/02 and G 10/02). The high productivity of diatoms and dinoflagellates during deposition of the Menilite Formation was facilitated by a wet climate and increased water runoff. The episodes of blooms of calcareous nannoplankton arose as a result of diminishing runoff and enhanced evaporation during drier phases (Sotak, 2010).

$\mathrm{HI}$ values decreasing to $95 \mathrm{mg} \mathrm{HC/g} \mathrm{TOC}$ in the $\mathrm{G} 08 / 02$ sample might be a result of OM degradation, due to the activity of bacterial sulphate reduction (Vető et al., 1995). Similar results were obtained for the Menilite Formation of the Outer Carpathians (Kotarba and Koltun, 2006) and other Oligocene units, such as the Ruslar Formation of the Kamchia Depression within the Eastern Paratethys (Sachsenhofer et al., 2009), and the Tard Clay of the Hungarian Paleogene Basin (Bechtel et al., 2012).

The positive excursion of $\delta^{13} \mathrm{C}_{\text {org }}$ in sample $\mathrm{G} 6 / 02$, correlating with high $\mathrm{HI}$ values and a slight percentage of terrestrial macerals, indicates the marine origin of OM because algal material comprises heavier isotopes in comparison to freshwater organic matter (Meyers, 1994; Bechtel et al., 2012).

The increased $\delta^{13} \mathrm{C}_{\text {org }}$ in the sample $\mathrm{G} 6 / 02$ is associated with lower $\mathrm{CaO}$ contents and might be explained by a drop in dissolved inorganic carbon. The most possible cause of heavy carbon rise is bio-productivity in the surface water.

A similar pattern was described for the Oligocene succession in the Austrian Molasse Basin (Schulz et al., 2002) and Hungarian Paleogene Basin (Bechtel et al., 2012). Negative values of $\delta^{13} \mathrm{C}_{\text {org }}$ within the GMF (G 7/02, G 8/02, G 10/02, $G 11 / 02$, and $G 12 / 02$ ) are probably related to marine incursion. Marine transgression could have overturned the water column and released ${ }^{12} \mathrm{C}$-rich $\mathrm{CO}_{2}$, which, used by primary producers, led to $\delta^{13} \mathrm{C}_{\text {org }}$ decreasing (Bechtel et al., 2012). It seems to be the explanation of org of the marly sample G 10/02. As a consequence of flooding, higher amounts of terrigenous, light-isotope OM also was able to be delivered into the basin that is assessed for the mudstone samples (G 7/02, G 8/02, G 11/02 and G 12/02).

DEPOSITIONAL ENVIRONMENTS AND DIAGENETIC THERMAL ALTERATION

Kaolinite comprises secondary minerals produced by the intense weathering of aluminum silicates such as feldspars. It is abundant in the samples studied, and is associated with interstratified illite/smectite (I/S). The (I/S) is potentially useful as a palaeotemperature indicator. The progressive transformation of smectite to illite is primarily controlled by temperature (Pollastro, 1993; Środoń, 1995). The thermal alteration of the GMF reflects palaeotemperatures reaching $140^{\circ} \mathrm{C}$. It corresponds with data obtained by Świerczewska (2005) for the Smilno and Świątkowa tectonic windows. The thermal alteration was accomplished before the Magura Nappe was thrusted into its current structural position.

Relatively constant amounts of $\mathrm{Al}_{2} \mathrm{O}_{3}$, with varying $\mathrm{CaO}$ contents, suggest that deposition took place under hemipelagic conditions. The $\mathrm{SiO}_{2}$ distribution through the section is similar to that of $\mathrm{Zr}$ and $\mathrm{Hf}$, reaching maximal concentrations in the samples $\mathrm{G} 7 / 02$ and $\mathrm{G} 17 / 02$. These samples contain chlorite, muscovite, and heavy minerals (see chapter Mineral composition), being typical terrigenous components.

The stable carbon isotope composition of carbonates $\left(\delta^{13} \mathrm{C}_{\text {carb }}\right)$ is a useful indicator of the salinity degree in the deposi- 
tion environment. According to Anderson and Arthur (1983), a decrease in $\delta^{13} \mathrm{C}_{\text {carb }}$ suggests decreasing salinity. In this context, it is most likely that the samples G 1/02, G 5/02 and G 7/02 of the GMF represent a marine environment influenced by freshwater inflow. In addition, light-isotope $C$ could have been produced by microbialites decomposition or have been released from methane buried in sediment (Peryt and Scholle, 1996; Bojanowski, 2007). Light $\delta^{13} C_{\text {carb }}$ values obtained in the Oligocene limestone in the Swiątkowa Wielka tectonic window indicate that the authigenic calcite precipitated as a result of the anaerobic oxidation of methane. Positive shifts of $\delta^{13} \mathrm{C}_{\text {carb }}$ in the samples G 10/02, G 12/02, G 13/02, and G 17/02 can indicate that balanced marine conditions re-occupied the basin at the end of the deposition period studied. Soták (2010) postulated that lightening of the carbon and oxygen isotopes of the black shales from the Menilite Formation resulted from the bacterial oxidation of organic matter. An intense influence of freshwater could not be excluded. Positive excursions in $\delta^{13} \mathrm{C}$ and $\delta^{18} \mathrm{O}$ might be linked with high coccolith productivity in surface waters rich in dissolved inorganic carbon.

The oxygen isotopes are sensitive to temperature changes (Tucker and Wright, 1990; Hoefs, 1997). If diagenetic recrystallisation had influenced the carbonates, $\mathrm{O}$ would have reflected the temperature of the secondary carbonate precipitation. The enrichment in light oxygen isotopes can be a consequence of diagenetic hot fluid activity. The discrepancy between the patterns of $\delta^{13} \mathrm{C}$ and $\delta^{18} \mathrm{O}$ of the carbonates (most visible in sample $\mathrm{G} 13 / 02$ : $\delta^{13} \mathrm{C}=-1.68 \% ; \delta^{18} \mathrm{O}=-4.80 \%$ ) suggests that enough fluids have passed through the GMF to alter the $\delta^{18} \mathrm{O}$ but not enough to alter the $\delta^{13} \mathrm{C}$ (Jacobsen and Kaufman, 1999). Analogous isotopic O composition was recorded in the Oligocene limestone in the Świątkowa Wielka tectonic window. The proportion of bicarbonate produced by the oxidation of methane (being a source of relatively light $C$ and heavy $\mathrm{O}$ ) to bicarbonate produced by the oxidation of organic matter (being a source of relatively heavy $C$ and light $O$ ) decreased upwards. As a result, the limestone isotopic composition changed upwards towards higher $\delta^{13} \mathrm{C}$ and lower $\delta^{18} \mathrm{O}$ values (Bojanowski, 2012).

Redox indicators. Pyrite framboids, concretions, and massive infills and overgrowths that are common in the materials studied are interpreted as preferentially formed in sediments near the redox transition (Wignall and Newton, 1998). The formation of pyrite nuclei probably began in the water column. Pyrite growth continued in the sediment during diagenesis.

Carbon-sulphur relationships. The redox conditions during sediment accumulation may influence various carbon-sulphur interactions. The sediments accumulated under normal marine conditions show a positive correlation between $S$ and $\mathrm{C}_{\text {org }}$. A lack of correlation between them and a positive intercept on the $S$ axis in the $S$ vs. TOC diagram suggests anoxic conditions. The TOC/S ratios between 0.5 and 5 describe anoxic conditions (Berner and Raiswell, 1983). The TOC/S ratios calculated for the Oligocene samples vary from 0.7 to 3.48 , indicating anoxic conditions. In the TOC-S plots (Fig. 10), many

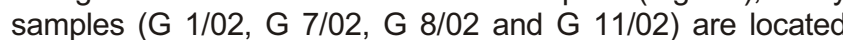
within "normal marine" fields. Two samples (G 5/02 and G 10/02) seem to be anoxic.

Redox-sensitive trace elements. Concentrations of $U$, Mo, Co, As, Ni and V increase upwards in the black and brown samples of the GMF. Uranium is incorporated into sediments after reduction to $U^{4+}$, stimulated by sulphate-reducing bacteria (Barnes and Cochran, 1990; Sani et al., 2004; Morford et al., 2005), therefore $U$ is concentrated in OM-rich deposits, often with pyrite association.
Molybdenum is scavenged by Fe-sulphides and humic substances in reducing conditions (Helz et al., 1996; Vorlicek et al., 2004). Cobalt is associated with organic acids, and it has an affinity with Fe-sulphides that serves as a carrier mineral also for As and Ni (Huerta-Diaz and Morse, 1992). Nickel is also preserved in pyrrole complexes in anoxic/euxinic conditions (Levan and Maynard, 1982).

The humic and fulvic acids facilitate the presence of vanadate and vanadyl compounds (Wilson and Weber, 1979). Under euxinic conditions, $V$ may be scavenged by porphyrins or be precipitated as a solid oxihydroxide phase (Breit and Wanty, 1991). The accumulation of $\mathrm{U}, \mathrm{Mo}, \mathrm{Co}, \mathrm{As}, \mathrm{Ni}$, and $\mathrm{V}$ can be associated with pyrite precipitation e.g. in the OM-rich, anoxic sediments of the GMF (G 5/02, G 7/02, G 8/02, G 10/02 and $G$ 11/02). Vanadium seems to be hosted by organic matter in the GMF, indicating reducing conditions.

Due to differences in the behaviour of $\mathrm{Ni}$ and $\mathrm{V}$ in an anaerobic environment, the $\mathrm{V} / \mathrm{V}+\mathrm{Ni}$ ratio has been used as a redox index. The ranges in ratio of $0.46-0.6$ and $0.54-0.82$ characterise dysoxic and anoxic conditions, respectively, whereas $\mathrm{V} / \mathrm{V}+\mathrm{Ni}$ $>0.84$ typifies an euxinic environment (Lewan and Maynard, 1982; Hatch and Leventhal, 1992). In the samples studied, the $\mathrm{V} / \mathrm{V}+\mathrm{Ni}$ range of 0.67 to 0.78 suggests anoxic conditions ( $\mathrm{Ta}-$ ble 2 and Fig. 8B).

The U/Th ranges from 0.75 to 1.25 , and $>1.25$ indicates dysoxic and anoxic conditions, respectively (Jones and Manning, 1994). The U/Th ratio for the deposits studied implies a change of aerobic to dysoxic-anoxic environment (Table 2 and Fig. 8B).

$\mathrm{V} / \mathrm{Cr}>2$ is regarded as being indicative of euxinic bottom waters, whereas the $\mathrm{V} / \mathrm{Cr}<1$ typifies normal oxic conditions (Dill, 1986; Jones and Manning, 1994). The ratio of the samples indicates an oxic environment changing to reducing conditions in the OM-rich samples of the GMF.

The Ni/Co ratio is $<5$ in the shales of normal oxic conditions. $\mathrm{Ni} / \mathrm{Co}$ values of 5 to 7 indicate dysoxic conditions, whereas $\mathrm{Ni} / \mathrm{Co}>7$ is known as an anoxic signature (Jones and Manning, 1994). The Ni/Co ratios obtained indicate an aerobic environment with a dysoxic outlier in $\mathrm{G} 11 / 02$.

The positive correlation between $\mathrm{Ni} / \mathrm{Co}$ and $\mathrm{V} / \mathrm{V}+\mathrm{Ni}$ (Fig. 9E) shows that the indicators are reliable. The flat relation between U/Th and V/V+Ni (Fig. 9F) suggests that trace element contents experienced diagenetic influence.

\section{CONCLUSIONS}

Deposition of the Grybów Marl Formation took place under hemipelagic conditions. The marine environment was occasionally influenced by an inflow of freshwater, delivering mineral detritus and organic matter. Then balanced marine conditions were re-established during the deposition of the upper part of the GMF and the Cergowa Beds.

Macerals assemblage, type II kerogen, and low $\delta^{13} \mathrm{C}_{\text {org. }}$ indicate land-plants as the main producers of organic matter. Fluvially-supplied nutrients could have initiated a plankton bloom. The high hydrogen index, the alginite occurrence, and the minor positive excursion in $\delta^{13} \mathrm{C}_{\text {org. }}$ suggest an algal contribution to the biomass, particularly obvious in $\mathrm{G} \mathrm{5/02,} \mathrm{G} \mathrm{06/02,}$ and $G 10 / 02$. The degradation of the organic matter facilitated an anoxic environment in the water column.

Anoxic to euxinic conditions prevailed in the water-column including photic zone during the deposition of the upper part of the GMF. This is probably linked to the Oligocene anoxic event, reflected by the widespread bituminous facies (e.g., the Menilite Formation of the Outer Carpathians, Maykop Shale of the East- 
ern Paratethys, and the Meletta shales of the Sub-Alpine Molasse).

The illitisation of smectite and the enrichment in light $\delta^{18} \mathrm{O}$ are probably results of the influence of diagenetic hot fluids. The morphotypes of pyrite and the erratic behaviour of the trace elements show that the sediment underwent diagenetic pyritisation.
Acknowledgements. The author is grateful to J. Soták and to two anonymous reviewers for their valuable remarks and improvements to the English version of the manuscript. Many thanks to T. Peryt for editorial work. The research was undertaken as part of a project of the Polish Ministry of Science and Higher Education grant (No. N N307 531038).

\section{REFERENCES}

Andreson, T.F., Arthur, M.A., 1983. Stable isotope of oxygen and carbon and their application to sedimentologic and paleoenvironmental problems. SEPM Short Course, 10: 1-151.

Báldi, T., 1980. The early history of the Paratethys. Bulletin of Hungarian Geological Society, 110: 456-472.

Barnes, C.E., Cochran, J.K., 1990. Uranium removal in oceanic sediments and the oceanic $U$ balance. Earth and Planetary Science Letters, 97: 94-101.

Bechtel, A., Hámor-Vidó, M., Gratzer, R., Sachsenhofer, R.F., Püttmann, W., 2012. Facies evolution and stratigraphic correlation in the early Oligocene Tard Clay of Hungary as revealed by maceral, biomarker and stable isotope composition. Marine and Petroleum Geology, 35: 55-74.

Berner, R.A., Raiswell, R., 1983. Burial of organic carbon and pyrite sulfur ion sediments over Phanerozoic time: a new theory. Geochimica et Cosmochimica Acta, 47: 855-862.

Breit, G.N., Wanty, R.B., 1991. Vanadium accumulation in carbonaceous rocks: A review of geochemical controls during deposition and diagenesis. Chemical Geology, 91: 83-97.

Bojanowski, M.J., 2007. Oligocene cold-seep carbonates from the Carpathians and their inferred relation to gas hydrates. Facies, 53: $347-360$

Bojanowski, M.J., 2012. Geochemical paleogradient in pore waters controlled by AOM recorded in an Oligocene laminated limestone from the Outer Carpathians. Chemical Geology, 292-293: 45-56.

Coplen, T.B., Brand, W.A., Gehre, M., Gröning, M., Meijer, H.J. Toman, B., Verkouteren, R.M., 2006. New guidelines for $\delta^{13} \mathrm{C}$ measurements. Analytical Chemistry, 78: 2439-2441.

Dill, H.,1986. Metallogenesis of Early Paleozoic graptolite shales from the Graefenthal Horst (Northern Bavaria-Federal Republic of Germany). Economic Geology, 81: 889-903.

Espitalié, J., Bordenave, M.L., 1993. Screening techniques for source rock evaluation: tools for source rocks routine analysis: Rock-Eval pyrolysis. In: Applied Petroleum Geochemistry (ed. M.L. Bordenave): 237-272.

Espitalié, J., Deroo, G., Marquis, F., 1985. La pyrolyse Rock-Eval et ses applications. Première partie. Oil \& Gas Science and Technology - Revue de I'Institut Francais du Petrole, 40: 563-579.

Hatch, J.R., Leventhal, J.S., 1992. Relationship between inferred redox potential of the depositional environment and geochemistry of the Upper Pennsylvanian (Missourian) stark shale member of the Dennis Limestone, Wabaunsee County, Kansas, USA. Chemical Geology, 99: 65-82.

Helz, G.R., Miller, C.V., Charnock, J.M., Mosselmans, J.F.W., Pattrick, R.A.D., Garner, C.D., Vaughan, D.J., 1996. Mechanisms of molybdenum removal from the sea and its concentration in black shales: EXAFS evidence. Geochimica et Cosmochimica Acta, 60: 3631-3642.

Hoefs, J., 1997. Stable Isotope Geochemistry, Springer-Verlag, 201 $\mathrm{pp}$.

Huerta-Diaz, M.A., Morse, J.W., 1992. Pyritization of trace metals in anoxic marine sediments. Geochimica et Cosmochimica Acta, 56: 2681-2702.
Jackson, M.L., 1975. Soil Chemical Analysis - Advanced Course. Madison, Wisconsin.

Jacobsen, S.B., Kaufman, A.J., 1999. The Sr, C and O isotopic evolution of Neoproterozoic seawater. Chemical Geology, 161: $37-57$.

Jones, B., Manning, D.A.C., 1994. Comparison of geochemical indices used for the interpretation of palaeoredox conditions in ancient mudstones. Chemical Geology, 111: 111-129.

Koráb, T., Ďurkovič, T., 1978. Geology of Dukla Unit (Flysch of the Eastern Slovakia) (in Slovak). SGÚDŠ, Bratislava, 194 pp.

Kotarba, M., Koltun, Y.V., 2006. Origin and habitat of hydrocarbons of the Polish and Ukrainian parts of the Carpathian Province. AAPG Memoir 84: 395-443.

Kotlarczyk, J., 1979. Uwagi o wieku margli bakulitowych (margli z Węgierki) w świetle formalnej rewizji oznaczeń fauny głowonogów i inoceramów (in Polish). Sprawozdania z Posiedzeń Komisji Naukowych PAN Kraków, VII-XII 1977: 103-105.

Kotlarczyk, J., Leśniak, T., 1990. Lower part of the Menilite Formation and related Futoma Diatomite Member in the Skole unit of the Polish Carpathians (in Polish with English summary). Wydawnictwo AGH, Kraków, 74 pp.

Kovač, M., Nagymarosy, A., Oszczypko, N., Ślączka, A. Csontos, L., Marunteanu, M., Matenco, L., Marton, E., 1998. Palinspastic reconstruction of the Carpathian-Pannonian region during the Miocene. In: Geodynamic Development of the Western Carpathias (ed. M. Rakus): 189-217. Slovak Geological Survey, Bratislava.

Kozikowski, H., 1956. Ropa-Pisarzowa unit, a new tectonit unit of the Polish flysch Carpathians (in Polish with English summary) Biuletyn Instytutu Geologicznego, 110: 93-137.

Książkiewicz, M., 1972. Budowa geologiczna Polski, t. IV Tektonika, cz. 3 Karpaty. Wyd. Geol., Warszawa, 228 pp.

Leszczyński, S., 1997. Origin of the Sub-Menilite Globigerina Marl (Eocene-Oligocene transition) in the Polish Outer Carpathians. Annales Societatis Geologorum Poloniae, 67: 367-427.

Lewan, M.D., Maynard, J.B., 1982. Factors controlling enrichment of vanadium and nickel in the bitumen or organic sedimentary rocks. Geochimica et Cosmochimica Acta, 46: 2547-2560.

Lexa, J., Bezak, V., Elecko, M., Mello, J., Polak, M., Potfaj, M., Vozar, J., 2000. Geological map of Western Carpathians and adjacent areas 1:500,000. Geol. Surv. Slovak Republic, Bratislava.

Mehra, O.P., Jackson, M.L., 1960. Iron oxide removal from soils and clays by a dithionite-citrate system buffered with sodium bicarbonate. Clays and Clay Minerals, $7: 317-327$

Meyers, P.A., 1994. Preservation of source identification of sedimentary organic matter during and after deposition. Chemical Geology, 144: 289-302.

Morford, J.L., Emerson, S.R., Breckel, E.J., Kim, S.H., 2005 Diagenesis of oxyanions $(\mathrm{V}, \mathrm{U}, \mathrm{Re}$, and $\mathrm{Mo})$ in pore waters and sediments from a continental margin. Geochimica et Cosmochimica Acta, 69: 5021-5032.

Olszewska, B., 1983. A contribution of the knowledge of planktonic foraminifers of the Globigerina Submenilite Marls of the Polish 
Outer Carpathians (in Polish with English summary). Kwartalnik Geologiczny, 27 (3): 547-570.

Oszczypko (Clowes), M., 1996. Calcareous nannoplankton of the Globigerina Marls (Leluchów Marls Member), Magura Nappe, West Carpathians. Annales Societatis Geologorum Poloniae, 66: 1-15.

Oszczypko, N., Oszczypko-Clowes, M., 2011. Stratigraphy and tectonics of the Świątkowa Wielka Tectonic Window (Magura Nappe, Polish Outer Carpathians). Geologica Carpathica, 62 139-154.

Oszczypko-Clowes, M., 2008. The stratigraphy of the Oligocene deposits from the Ropa tectonic window (Grybów Nappe, Western Carpathians, Poland). Geological Quarterly, 52 (2): 127-142.

Oszczypko-Clowes, M., Oszczypko, N., 2004. The position and age of the youngest deposits in the Mszana Dolna and Szczawa tectonic windows (Magura Nappe, Western Carpathians, Poland). Acta Geologica Polonica, 54: 339-367.

Oszczypko-Clowes, M., Ślączka, A., 2006. Nannofossil biostratigraphy of the Oligocene deposits in the Grybów tectonic window (Grybów Unit, Western Carpathians, Poland). Geologica Carpathica, 57: 473-482.

Peryt, T.M., Scholle, P.A., 1996. Regional setting and role of meteoric water in dolomite formation and diagenesis in an evaporite basin: studies in the Zechstein (Permian) deposits of Poland. Sedimentology, 43: 1005-1023.

Peters, K.E., Moldowan, J.M., 1993. The Biomarker Guide, Interpreting Molecular Fossils in Petroleum and Ancient Sediments. Prentice Hall, Englewood Cliffs, NJ United States.

Pollastro, R., 1993. Considerations and applications of the illite/smectite geothermometer in hydrocarbon-bearing rocks of Miocene to Mississippian age. Clays and Clay Minerals, 41: 119-133.

Popov, S.V., Akhmetíev, M.A., Zaporozhets, N.I., Voronina, A.A., Stolyarov, A.S., 1993. Evolution of Eastern Paratethys in the late Eocene-early Miocene. Stratigraphy and Geological Correlation, 1: 10-39.

Popov, S.V., Rögl, F., Rozanov, A.Y., Steininger, F.F., Shcherba, I.G., Kovac, M., 2004. Lithological-Paleogeographic maps of Paratethys - 10 maps Late Eocene to Pliocene. Courier Forschungsinstitut Senckenberg, 250: 1-46.

Rögl, F., 1999. Mediterranean and Paratethys. Facts and hypotheses of an Oligocene to Miocene paleogeography (short overview). Geologica Carpathica, 50: 339-349.

Rusu, A., 1988. Oligocene events in Transylvania (Romania) and the first separation of Paratethys. Dari de Seama ale Institutului de Geologie şi Geofizică, 72-73: 207-223.

Sachsenhofer, R.F., Schulz, H.-M., 2006. Architecture of Lower Oligocene source rocks in the Alpine Foreland Basin: a model for syn- and postdepositional source rock features in the Paratethyan Realm. Petroleum Geoscience, 12: 363-377.

Sachsenhofer, R.F., Stummer, B., Georgiev, G., Dellmour, R., Bechtel, A., Gratzer, R., Coric, S., 2009. Depositional environment and hydrocarbon source potential of the Oligocene Ruslar Formation (Kamchia Depression; western Black Sea). Marine and Petroleum Geology, 26: 57-84.

Sani, R.K., Peyton, B.M., Amonette, J.E., Geesey, G.G., 2004. Reduction of uranium(VI) undersulfate-reducing conditions in the presence of $\mathrm{Fe}(\mathrm{III})$-(hydr)oxides. Geochimica et Cosmochimica Acta, 68: 2639-2648.

Schulz, H.-M., Sachsenhofer, R.F., Bechtel, A., Polesny, H., Wagner, L., 2002. The origin of hydrocarbon source rocks in the Austrian Molasse Basin (Eocene-Oligocene transition). Marine and Petroleum Geology, 19: 683-709.

Schulz, H.M., Bechtel, A., Sachsenhofer, R.F., 2005. The birth of the Paratethys during the Early Oligocene: from Tethys to an an- cient Black Sea analogue? Global and Planetary Change, 49: 163-176.

Sikora, W., 1960. On the stratigraphy of the series in the tectonic window at Ropa near Gorlice (Western Carpathians) (in Polish with English summary). Kwartalnik Geologiczny, 4 (1): 153-170.

Sikora, W., 1970. Geology of the Magura Nappe between Szymark Ruski and Nawojowa (in Polish with English summary). Biuletyn Instytutu Geologicznego, 235: 5-121.

Ślączka, A., 1971. Geology of the Dukla Unit (in Polish with English summary). Prace Instytutu Geologicznego, 1: 1-63.

Soták, J., 2010. Paleoenvironmental changes across the Eocene-Oligocene boundary: insights from the Central-Carpathian Paleogene Basin. Geologica Carpathica, 61: $1-26$.

Stopes, M.C., 1935. On the petrology of banded bituminous coals. Fuel, 14: 4-13.

Środoń, J., 1995. Reconstruction of maximum paleotemperatures at present erosional surface of the Upper Silesia Basin, based on the composition of illite/smectite in shales. Studia Geologica Polonica, 108: 9-22.

Świdziński, H., 1963. Les couches de Grybów et leur importance pour latectonique des Karpates. Resume des communications. Congr. Geol. Ass. Karp.-Balk., 6: 191-193. Warszawa-Kraków.

Świerczewska, A., 2005. Illite-smectite as an indicator of variable uplift in the Magura Nappe (Outer Carpathians). Polskie Towarzystwo Mineralogiczne Prace Specjalne, 25: 381-386.

Tucker, M.E., Wright, V.P., 1990. Carbonate Sedimentology. Blackwell, Oxford

Uhlig, V., 1888. Ergebnisse geologischer Aufnahmen in den westgalizischen Karpathen. Jahrbuch der Geologischen Reichsanstalt, 38: 85-264.

Vetö, I., 1987. An Oligocene sink for organic carbon: upwelling in the Paratethys? Palaeogeography, Palaeoclimatology, Palaeoecology, 60: 143-153.

Vető, I., Hetényi, M., Demény, A., Hertelendi, E., 1995. Hydrogen index as reflecting sulphidic diagenesis in non-bioturbated shales. Organic Geochemistry, 22: 299-310.

Vorlicek, T.P., Kahn, M.D., Kasuza, Y., Helz, G.R., 2004. Capture of molybdenum in pyrite-forming sediments: role of ligand-induced reduction by polysulfides. Geochimica et Cosmochimica Acta, 68: 547-556.

Wedepohl, K.H., 1971. Environmental influences on the chemical composition of shales and clays. In: Physics and Chemistry of the Earth (eds. L.H. Ahrens, F. Press, S.K. Runcorn and H.C Urey): 307-331. Pergamon, Oxford.

Whitney, D.L., Evans, B.W., 2010. Abbreviations for names of rock-forming minerals. American Mineralogist, 95: 185-187.

Wignall, P.B., 1994. Black Shales. Oxford University Press, Oxford.

Wignall, P.B., Newton, R., 1998. Pyrite framboid diameter as a measure of oxygen deficiency in ancient mudrocks. American Journal of Science, 298: 537-552.

Wilson, S.A., Weber, J.H., 1979. An EPR study of the reaction of vanadium (IV) by fulvic acid. Chemical Geology, 26: 345-354.

Ziegler, P., Roure, F., 1999. Petroleum systems of Alpine-Mediterranean foldbelts and basins. Geological Society London Special Publications, 156: 517-540.

Żytko, K., Gucik, S., Ryłko, W., Oszczypko, N.,. Zając, R., Garlicka, L., Nemčok, J., Eliaš, M., Menčik, E., Dvorak, J., Stranik, Z., Rakuč, M., Matejovska, O., 1989. Geological map of the Western Outer Carpathians and their foreland without Quaternary formations. In: Geological Atlas of the Western Outer Carpathians and Their Foreland. Państwowy Instytut Geologiczny, Warszawa. 